\title{
FIVE STRATEGIES OF ENTREPREUNEURSHIP LEARNING UNTUK MENGHASILKAN REAL ENTREPEUNEUR (MODEL PENDIDIKAN ENTREPREUNEURSHIP DI PERGURUAN TINGGI)
}

\author{
Dadan Rosana*, Suwarna ${ }^{* *}$, Vinta A. Tiarani ${ }^{* * *}$ \\ * FMIPA, ${ }^{* *}$ FBS, dan ${ }^{* * *}$ FIP Universitas Negeri Yogyakarta \\ (danrosana.uny@gmail.com)
}

\begin{abstract}
Abstrak. Five Strategies of Entrepreuneurship Learning untuk Menghasilkan Real Entrepeuneur (Model Pendidikan Entrepreuneurship di Perguruan Tinggi). Tujuan penelitian ini menghasilkan suatu model pembelajaran yang dapat mengembangkan kemampuan entrepreuneur secara nyata pada mahasiswa melalui implementasi lima Strategies of Entreprueneurship Learing dalam kuliah kewirausahaan melalui pembentukan mid-set, attitude, skills, dan knowledge. Metode penelitian menggunakan Research and Development lewat lima Fase Perancangan Pengajaran Model Spiral diadaptasi dari 'Five phases of instructional design' dari Cennamo dan Kalk. Pengembangan dimulai dari fase definisi, desain, peragaan, pengembangan, dan penyajian yang pihak-pihak calon pengguna, ahli bidang yang dikembangkan, anggota tim dan instruktur, dan pembelajar. Hasil penelitian berupa model pembelajaran kewirausahaan yang terdiri atas lima strategi pembelajaran yang dilaksanakan secara terpadu, yaitu creative critical constructive imagination, entrepreneurial real life experience, educative disequilibrium conditioning, coaching and mentoring with collaboration and competition, dan community and market impact and involvement. Ujicoba terbatas menunjukkan adanya peningkatan proses dan hasil belajar dari aspek kognitif, afektif, dan keterampilan berwirausaha. Model hipotetik yang digunakan menunjukkan indikasi tercapainya hasil yang sesuai dengan rancangan awal, yaitu wirausaha baru berbasis ilmu pengetahuan. Bentuk usaha dikaitkan dengan kegiatan Program Kreativitas Mahasiswa Kewirausahaan di antaranya bakso krokot (obat asam urat), minuman kesehatan adas manis (Miss Anis) yang sudah dilengkapi izin Depkes dan Deperindag, tas biji asam, dan keripik biji mahoni (minuman kesehatan).
\end{abstract}

Kata Kunci: entrepreuneurship learning, real entrepeuneur, research and development

Abstract: Five Strategies of Entrepreneurship Learning (5 SoEL) to Develop Real
Entrepreneur (Educational Model of Entrepreneurship at Higher Education).
The general purpose of conducting this study is to design a learning model which
can develop entrepreneur's capability of entrepreneurship in real context through
the implementation of Five Strategies of Entrepreneurship Learning (5 SOEL) in
entrepreneurship course through the shaping process of mind-set, attitude, skill 
and knowledge (MASK) as a real entrepreneur. Stages done to achieve the purposes are: (1) to design learning model to increase the ability of critical thinking, to change mind-set, (2) Learning experience in term of real-life experience, i.e. entrepreneurship experience, (3) the learning process is designed and conditioned to help students learn through disequilibrium condition, (4) through cooperation and competition, students is taught how to learn to cooperate and rise their strength well, (5) get students involved in the life of society. Research method used is Research and Development (R\&D) which uses five phases of spiral model of teaching design adapted from "five phases of instructional design" of Cennamo and Kalk (2005:6). In this spiral model, there are five phases of developing, they are: (1) defining, (2) designing, (3) demonstrating, (4) developing, and (5) delivering. The finding of the research done through research and development stages has shown the increasing process and the outcome of educational process which are significant enough in term of cognitive and affective aspects and skill in running a business as well. Business area which are started to develop by group of students, among them are Bakso Krokat (obat asam urat), healthy drinking of Adas Manis (Miss Anis) which has been registered in Ministry of Health and Ministry of Domestic Affair, bags made from sour seed, and ships made of mahogany seeds (health).

Keywords: entrepreuneurship learning, real entrepeuneur, research and development

\section{PENDAHULUAN}

Badan Pusat Statistik (BPS) mengungkapkan bahwa pengangguran terdidik (intelektual) di Indonesia terus mengalami peningkatan sejak beberapa tahun terakhir. Setiap tahun perguruan tinggi di Indonesia menghasilkan lebih dari 300.000 lulusan, namun daya serap lapangan kerja untuk mereka terlalu sedikit, sehingga pada bulan Februari 2007 terdapat lebih dari 740.000 lulusan perguruan tinggi yang menganggur. Hal ini sangat mencemaskan karena angka ini cenderung naik pesat dari waktu ke waktu. Dalam waktu enam bulan, dari Agustus 2006 hingga Februari 2007, penganggur terdidik naik sebesar 66.578 orang (9,88 persen), artinya dalam setahun bisa mencapai
20 persen. Lebih menyedihkan lagi bila kita mengikutkan kelompok penganggur terdidik yang setengah menganggur. Pada bulan Februari 2007 sudah terdapat 1,4 juta, atau naik sekitar 26 persen dibandingkan Februari 2006. dan pada akhir tahun 2009 diperkirakan akan ada 1.100.000 orang penganggur terdidik di Indonesia (http:/kwww.solopos.com).

Semakin membengkaknya lulusan perguruan tinggi yang menganggur semakin menunjukkan bahwa ketersediaan lapangan kerja yang sangat terbatas. Hal ini tentu saja disebabkan oleh banyak faktor yang sangat kompleks. Namun demikian, salah satu solusi yang sangat realistis untuk diwujudkan adalah melalui usaha pe- 
ningkatan kualitas pembelajaran di Perguruan Tinggi, khususnya diperlukan model pembelajaran entrepreuneurship yang tepat sesuai dengan karakteristik bidang keilmuan (intrapreuneurship). Model pembelajaran itu harus mampu membentuk mid-set, attitude, skills, dan sekaligus knowledge (MASK) berkaitan dengan entrepreuneurship. Karena itu, dalam penelitian ini akan dikembangkan sebuah model pembelajaran yang pada intinya terdiri dari 5 strategi pembelajaran entrepreuneurship, yaitu; creative critical constructive imagination, entrepreneurial real life experience, educative disequilibrium conditioning, coaching and mentoring with collaboration and competition, dan community and market impact and involvement.

Penelitian ini didukung beberapa teori yang relevan sesuai dengan tahap pertama dalam desain penelitian dan pengembangan (R\&D) yaitu define. Peterman dan Kennedy dalam Frazier (2009) menemukan bahwa pengalaman yang positif dalam kegiatan kewirausahaan pada bisnis kecil mempunyai pengaruh terhadap minat kewirausahaan. Penelitian Reitan dalam Frazier (2009) menemukan bahwa pengalaman kerja pada bisnis mempunyai pengaruh positif pada minat kewirausahaan.

Penelitian Rotefoss dan Kolvereid dalam Kautonen et al. (2008) menunjukkan bahwa pengalaman kewirausahaan sebelumnya yang positif mempengaruhi kemungkinan mendirikan bisnis dan ada perbedaan antara wirausaha yang baru pertama kali berbisnis (novice entrepreneurs) dengan wirausaha yang sudah memiliki bisnis sebelumnya (serial entrepreneurs). Menurut
Ucbasaran et al. dalam Kautonen et al. (2008) serial entrepreneurs menikmati pengalaman dan manfaat kewirausahaan dibandingan novice entrepreneurs karena serial entrepreneurs memiliki kesempatan untuk mendapatkan sumbersumber daya dan belajar dari karir wirausaha sebelumnya.

Model pembelajaran entrepreuneurship yang dikembangkan mengacu pada Joyce dan Weil (1992:14-16), bahwa model pembelajaran mempunyai unsur: (1) sintaks; (2) sistem sosial; (3) prinsip-prinsip reaksi; (4) sistem pendukung; (5) dampak instruksional; dan (6) dampak pengiring. Sedangkan kualitas model didasarkan pada pendapat Nieveen (1999:127-128) yang menyatakan bahwa, suatu model berkualitas baik jika memenuhi kriteria kesahihan (validity), kepraktisan (practicality), dan keefektifan (effectiveness). Aspek kesahihan berkaitan dengan dua hal, yaitu: (1) model yang dikembangkan harus didasarkan pada rasional teoritik yangkokoh (state-of-the-art knowledge); dan (2) komponen-komponen model yang dikembangkan harus konsistensecara internal (internally consistent).

Aspek kepraktisan berkaitan dengan dua hal, yaitu: (1) menurut penilaian ahli dan praktisi, model yang dikembangkan harus dapat diterapkan (intended-perceived); dan (2) secara operasional di lapangan, model yang dikembangkan dapat diterapkan (intended-operational). Aspek keefektifan berkaitan dengan dua hal, yaitu: (1) menurut penilaian ahli dan praktisi, model yang dikembangkan memenuhi syarat efektif (intended-experiential); dan 
(2) secara operasional di lapangan, model yang dikembangkan sesuai de- ngan keefektifan yang diharapkan (intended-attained).

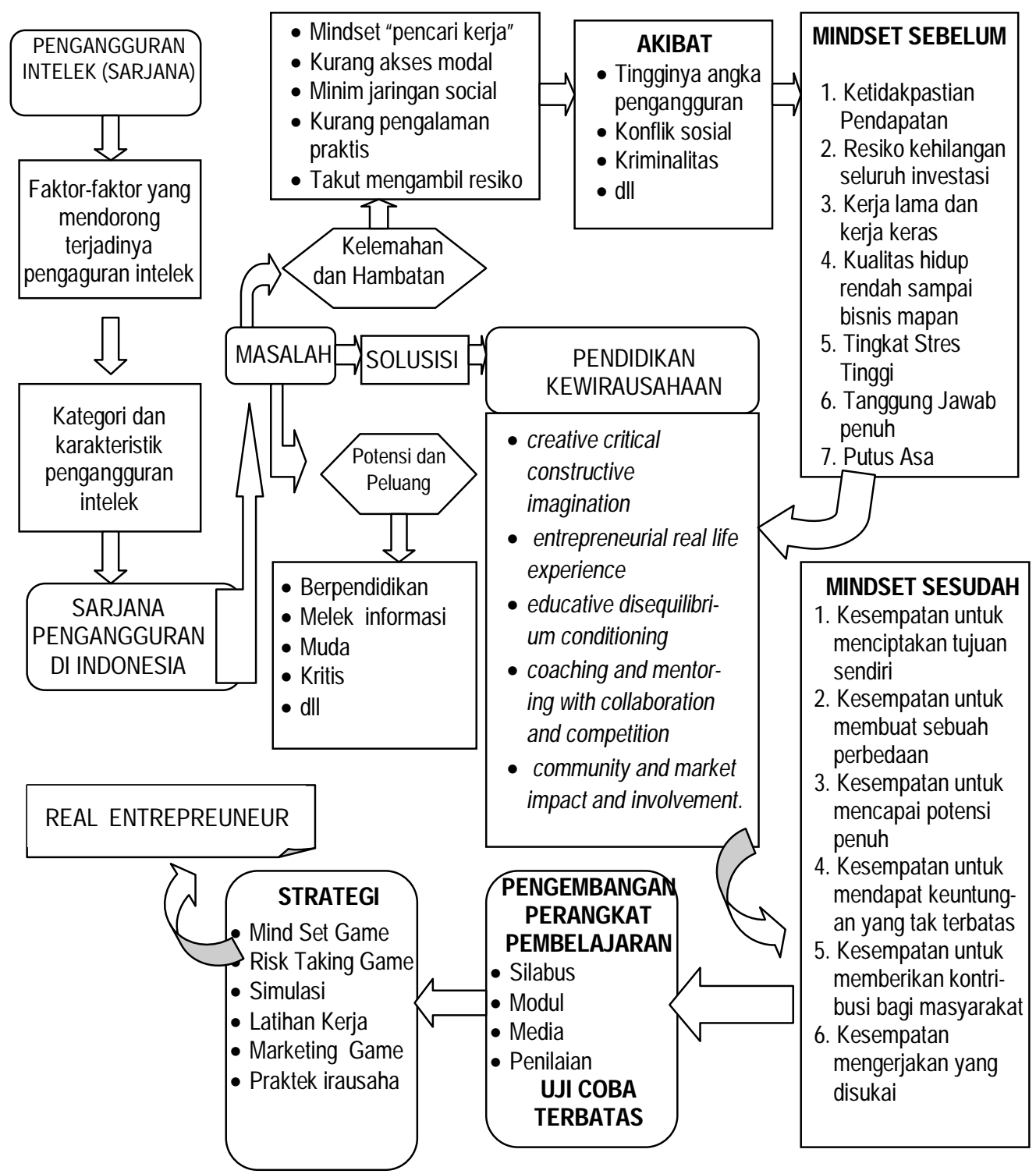

\section{Gambar 1. Kerangka Pikir Pengembangan Model Lima Strategies of Entrepreuneurship Learning}

Berdasarkan latar belakang masalah dan landasan teori yang relevan, maka tujuan khusus dari penelitian ini adalah (1) meningkatkan kemampuan berfikir kritis, imajinatif dan kreatif mahasiswa peserta kuliah kewirausahaan dengan cara memberikan stimulasi dan latihan yang tepat se- 
hingga mampu mengintegrasikan kedua belahan hemisphere, baik belahan otak kanan maupun belahan otak kiri, sehingga muncul imajinasi sebagai bagian penting dari sebuah inovasi di bidang wirausaha; (2) memberikan pengalaman belajar dalam bentuk reallife experience kewirausahaan untuk menghasilkan real entrepreuneur, sehingga mahasiswa merasakan secara langsung liku-liku kehidupan kewirausahaan secara nyata sebagai sebuah pembelajaran bermakna; (3) merancang pembelajaran yang dikondisikan untuk membantu peserta didik belajar melalui kondisi disekuilibrium yang disimulasikan karena penting untuk memberikan pengalaman gagal dalam berwirausaha dan menemukan solusinya; (4) mengembangkan strategi kerjasama dan kompetisi untuk melatih mahasiswa berkolaborasi dengan baik dan meningkatkan keunggulan mereka melalui persaingan usaha yang berarti; (5) melibatkan mahasiswa dalam kehiduan kewirausahaan secara nyata di masyarakat melalui penyertaan modal ventura dan pendampingan untuk melatihkan mind-set, attitude, skills, dan knowledge sehingga mampu memberikan dampak kemanfaatan bagi masyarakat sekitarnya.

Tujuan penelitian tersebut dapat dicapai melalui pengembangan kerangka pikir seperti tampak pada Gambar 1 di atas.

\section{METODE}

Model pembelajaran yang dikembangkan dalam penelitian ini adalah merupakan model konseptual. Prosedur pengembangan mengacu pada bingkai penelitian dan pengembangan (research and development) dengan melalui tiga tahapan yaitu tahap pertama dilakukan studi literatur dan penelitian eksploratif ke lapangan terhadap pembelajaran kewirausahaan yang dilakukan di UCEC (University of Ciputra Entrepreuneurship Centre) dan study kasus di Program Studi IPA, FMIPA Universitas Negeri Yogyakarta (UNY). Hasil studi literatur dan penelitian eksploratif berupa abstraksi model konseptual desain pembelajaran kewirausahaan dengan menggunakan 5 strategies of entrepreuneurship learning (5 SoEL). Pada tahap kedua yaitu tahap pengembangan, menyusun konstruksi sebagai draf awal desain pembelajaran kewirausahaan dengan pemodelan 5 SoEL, kemudian dilakukan validasi teoretik melalui diskusi terfokus dengan teman sejawat, justifikasi dan konsultasi ahli. Hasil validasi teoretik dipakai untuk merekonstruksi desain pembelajaran kewirausahaan yang siap diujicobakan. Tahap ketiga atau tahap akhir melakukan uji coba desain pembelajaran kewirausahaan sebagai validasi empirik yang menghasilkan produk penelitian berupa model empirik desain pembelajaran Kewirausahaan dengan 5 SoEL.

Untuk menghasilkan model pembelajaran tersebut, metode penelitian yang digunakan adalah Research and Development (R\&D) dengan menggunakan Lima Fase Perancangan Pengajaran Model Spiral diadaptasi dari 'Five phases of instructional design' dari Cennamo dan Kalk, (2005:6). Dalam model spiral ini dikenal 5 (lima) fase pengembangan yakni: (1) definisi (define); 
(2) desain (design); (3) peragaan (demonstrate); (4) pengembangan (develop); dan (5) penyajian (deliver). Pengembang dimulai dari fase definisi (yang merupakan titik awal kegiatan), menuju ke arah fase desain, peragaan, pengembangan, dan penyajian yang dalam prosesnya berlangsung secara spiral dan melibatkan pihak-pihak calon pengguna, ahli dari bidang yang dikembangkan (subject matter experts), anggota tim dan instruktur, dan pembelajar.

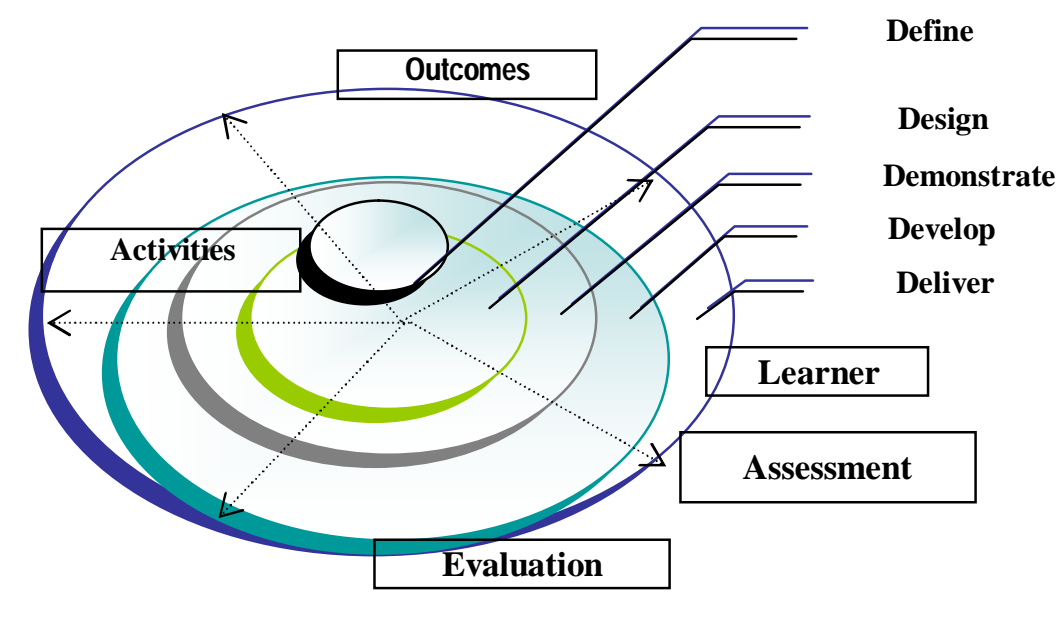

\section{Gambar 2. Lima Fase Perancangan Pengajaran Model Spiral diadaptasi dari 'Five Phases of Instructional Design' dari Cennamo dan Kalk, (2005:6)}

Keterangan :
Proses pengembangan akan berlangsung mengikuti gerak secara siklus iterative (iterative cycles) dari visi definisi yang samar menuju ke arah produk yang konkret yang teruji efektivitasnya, sebagaimana yang direferensikan oleh Dorsey, Goodrum, \& Schwen, 1997 (Cennamo \& Kalk, 2005:7) yang dikenal dengan "the rapid prototyping process".
Pengembang dalam setiap fase pengembangan akan selalu bolak-balik berhadapan ulang dengan elemenelemen penting rancangan pengajaran yaitu tujuan akhir, kegiatan belajar, pebelajar, asesmen dan evaluasi.

\section{HASIL}

Penelitian dan pengembangan ini menghasilkan produk utama berupa 


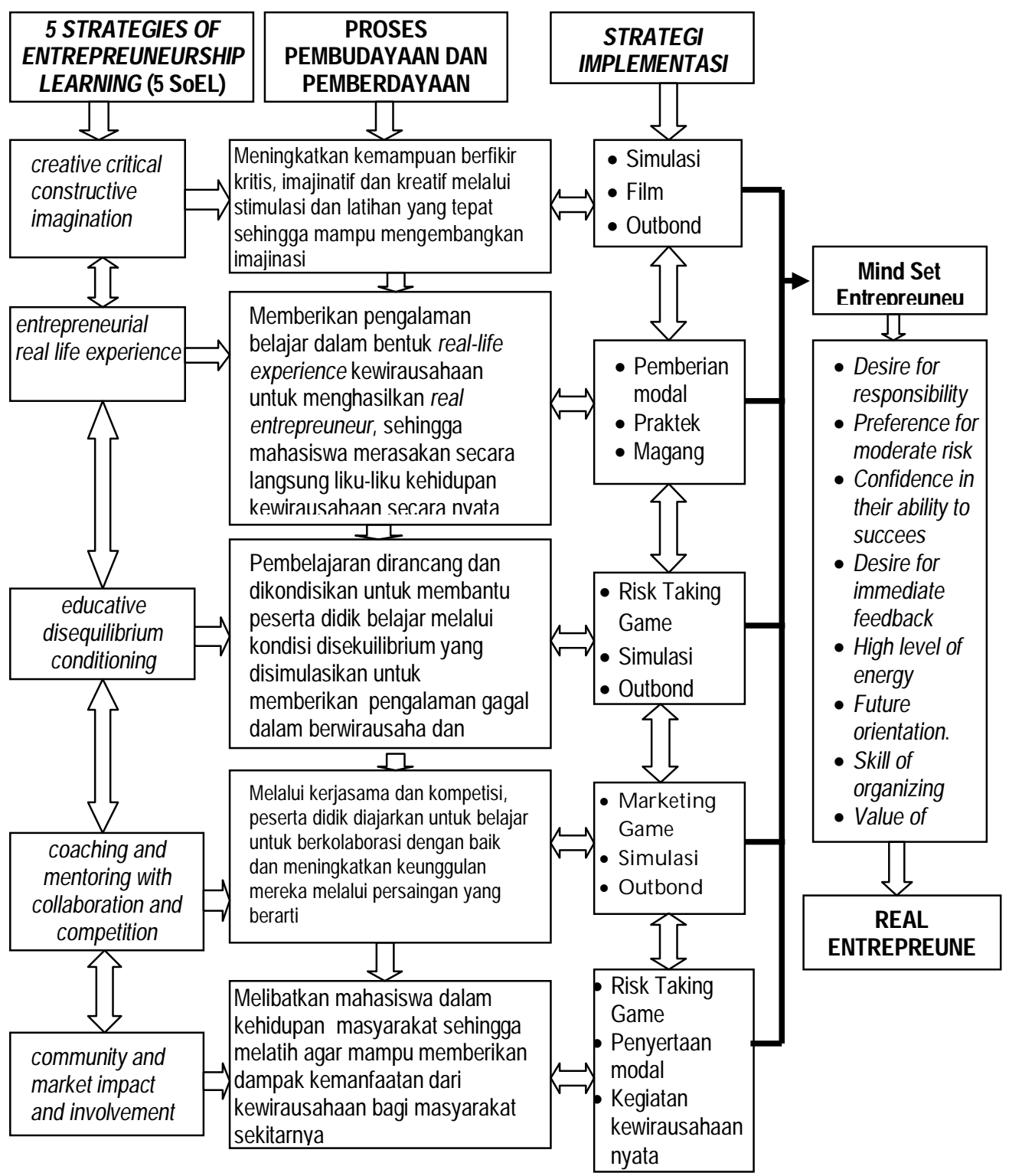

Gambar 3. Model Penerapanan Lima SoEL

Keterangan:

Karakteristik kepribadian dari seorang wirausaha sukses yakni:

- Desire for responsibility yakni memiliki rasa tanggung jawab atas usaha-usaha yang dilakukannya.
- Preference for moderate risk yakni memilih resiko yang moderat dan telah diperhitungkan dan tidak mengambil resiko yang terlalu rendah atau terlalu tinggi.

- Confidence in their ability to succees yakni percaya bahwa dirinya bisa 
meraih kesuksesan yang diinginkannya.

- Desire for immediate feedback yakni memiliki keinginan untuk segera mendapatkan umpan balik.

- High level of energy yakni memiliki semangat dan energi yang tinggi untuk bekerja keras mencapai tujuannya.

- Future orientation yakni berorientasi pada masa depan dan jangka panjang.

- Skill of organizing yakni mempunyai keterampilan mengorganisir sumbersumber daya untuk mencapai tujuannya.

- Value of achievement over money yakni lebih menghargai prestasi dibandingkan uang, karena uang akan mengalir masuk dengan sendirinya jika seorang wirausaha mempunyai prestasi yang bagus.

Melalui tahapan kegiatan yang terstruktur dan sistematis, empat tujuan dari penelitian ini yang telah direalisasikan adalah (1) tersedianya bahan ajar berupa silabus, RPP, Modul bahan ajar cetak (BAC), Worksheet, blue print, dan Film pembelajaran; (2) diterapkannya model pembelajaran 5 Strategies of Entreprueneurship Learing (5SoEL) dalam kuliah kewirausahaan melalui pembentukan mid-set, attitude, skills, dan knowledge (MASK). Model pembelajaran yang dikembangkan dalam penelitian ini pada intinya terdiri dari 5 strategi pembelajaran entrepreuneurship, yaitu; creative critical constructive imagination, entrepreneurial real life experience, educative disequilibrium conditioning, coaching and mentoring with collaboration and competition, dan commu- nity and market impact and involvement, (3) terlaksananya pembelajaran dalam bentuk real-life experience berupa pengalaman wirausaha, karena teori saja tidak cukup untuk membangun seorang real entrepreuneur, sehingga mahasiswa juga harus merasakan kehidupan kewirausahaan nyata untuk benar-benar mengerti kewirausahaan; dan (4) telah dilakukan analisis data, evaluasi dampak, ouput dan outcome dari kegiatan penelitian, dilanjutkan dengan sosialisasi dan penyiapan artikel publikasi.

\section{PEMBAHASAN}

Hasil penelitian yang di dapatkan dari tahapan penelitian pengembangan (R\&D) dari model pembelajaran 5SoEL, adalah berupa peningkatan proses dan hasil belajar yang cukup signifikan baik dari aspek kognitif, afektif, dan keterampilan berwirausaha. Meskipun secara kuantitatif model yang dikembangkan masih harus diuji melalui tahapan deseminasi namun model hipotetik yang digunakan telah memberikan hasil yang sesuai dengan rancangan awalnya, yaitu menghasilkan wirausaha baru berbasis ilmu pengetahuan. Bentuk usaha yang mulai dikembangkan oleh kelompok mahasiswa, di antaranya (1) Bakso Krokot (obat asam urat); (2) Minuman Kesehatan Adas Manis (Miss Anis) yang sudah dilengkapi izin dari Depkes dan Derperindag; (3) Tas Biji Asam; dan (4) Keripik biji mahoni (makanan kesehatan).

Dalam pelaksanaan penelitian, pembahasan mengikuti pada 5 (lima) fase pengembangan dari Cennamo dan Kalk (2005:6), yaitu; 1) definisi (define); 
2) desain (design); 3) peragaan (demonstrate); 4) pengembangan (develop); dan 5) penyajian (deliver).

\section{Tahap Pendefinisian}

Pada tahap pendefinisian ini pertama kali dilakukan kajian teoritis terhadap berbagai konsep yang terkait dengan pengembangan model 5 SoEL. Pada tahap pengujian teoretis ini, pertama kali rancangan yang telah dibuat oleh peneliti direviu oleh seorang pakar pendidikan. Tujuannya adalah untuk merevisi dan mendapatkan masukkan tentang pengembangan konsep-konsep ilmiah yang digunakan dalam penelitian ini.

\section{Tahap Perancangan}

Tujuan dari tahap ini adalah untuk merancang atau merencanakan suatu bentuk perangkat pembelajaran. Termasuk pada tahap ini adalah menjabarkan indikator pencapaian hasil belajar yang didasarkan pada kompetensi dasar yang ingin dicapai. Dari indikator ini dibuat kisi-kisi evaluasi kemampuan menggunakan alat ukur. Dalam tahapan ini juga dilakukan perencanaan, termasuk; mendefinisikan keterampilan-keterampilan, merumuskan tujuan, menentukan urutan penyajian materi, dan evaluasi skala kecil yang dapat diterapkan.

\section{Hasil Perancangan Perangkat Pem- belajaran}

Kegiatan pengembangan perangkat pembelajaran dalam kegiatan penelitian ini mengadopsi model spiral sebagaimana yang direferensikan oleh Cennamo dan Kalk (2005:6) dan telah berhasil mengembangkan perangkat pembelajaran yang diperlukan dalam proses belajar mengajar kewirausahaan di perguruan tinggi. Perangkat pembelajaran yang berhasil dikembangkan adalah (1) perangkat outbond sebagai media pengembangan pembelajaran hands-on dan mainds-on untuk mengembangkan keterampilan proses dan kreativitas; (2) modul kewirausahaan; (3) Silabus dan Rancangan Pelaksanaan Pembelajaran (RPP); (4) Lembar Kegiatan (LK); dan (5) Instrumen Evaluasi untuk 5 SoEL.

Perangkat pembelajaran tersebut telah diujicobakan di 2 kelas kewirausahaan (Pendidikan IPA dan Pendidikan Fisika) dengan jumlah mahasiswa 32 orang. Selanjutnya, diuraikan masing-masing perangkat pembelajaran tersebut serta catatan-catatan selama pengembangan, terutama catatan dari kegiatan revisi berdasarkan masukan dari validator, kegiatan simulasi, dan masukan dari hasil ujicoba.

Perangkat outbond sebagai Media Pengembangan Pembelajaran Handson dan Minds-on untuk Mengembangkan Keterampilan Proses dan Kreativitas

Dengan mengacu pada silabus kewirausahaan yang dikembangkan berdasarkan TOT dengan UCEC dan Bank Mandiri, maka disusunlah perangkat alat demonstrasi dan eksperimen untuk mata pelajaran kewirausahaan. Hasil yang dikembangkan kemudian di konsultasikan dengan para dosen melalui kegiatan sosialisasi dan deseminasi terbatas. 


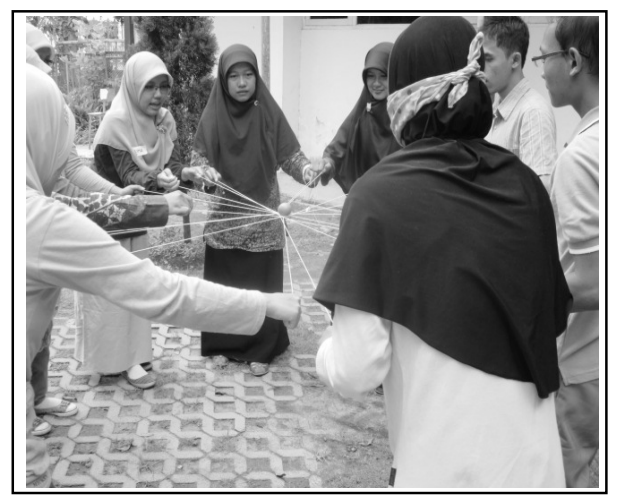

Gambar 4. Game Membangun Kerjasama

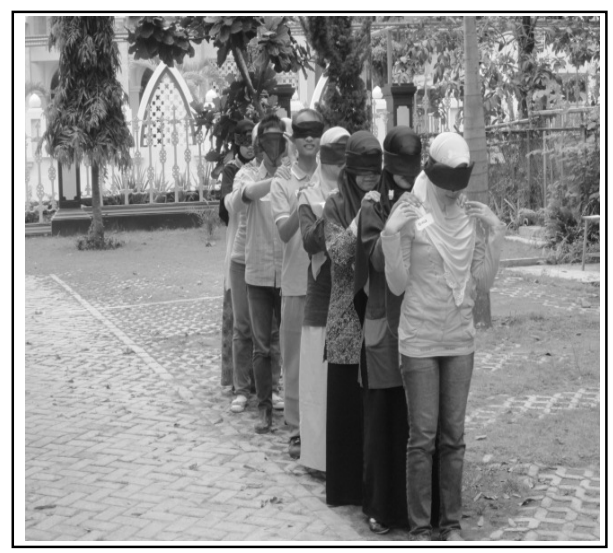

Gambar 5. Game Kepeminpinan

\section{Modul untuk Pengembangan 5 SoEL}

Modul adalah materi ajar yang merupakan pegangan mahasiswa sebagai panduan dalam proses pembelajaran kewirausahaan. Modul dikembangkan dengan mengacu pada silabus yang disusun pada saat TOT dengan UCEC dan Bank Mandiri dan kemudian disempurnakan dengan sesuai dengan rancangan model 5 SoEL. Tingkat penguasaan konsep, prinsip, fakta, dan contoh-contoh pada bahan ajar yang disusun tersebut disempurnakan dengan mengadopsi dari sum- ber-sumber lain yang dianggap relevan. Buku lain yang digunakan oleh peneliti untuk menyempurnakan modul adalah seperti yang tercantum pada bagian daftar pustaka modul. Modul mahasiswa terdiri dari 86 halaman dengan muatan sebagai berikut.

- Bagian awal, terdiri dari (1) tujuan pembelajaran yang hendak dicapai yang meliputi tujuan produk, tujuan proses, tujuan afektif, dan tujuan kreatif dan tujuan aplikatif; (2) fokus bab; dan (3) gambaran umum bahan kajian yang dipelajari pada masingmasing sub-pokok bahasan.

- Bagian inti, yang meliputi uraian tentang konsep air, udara, dan energi (prinsip, konsep, fakta, dan contoh-contoh). Urutan isi materi diawali dengan topik yang disusun sedemikian rupa sehingga dapat digunakan untuk mengembangkan 5 SoEL.

- Bagian akhir materi ajar, berisikan rangkuman materi dan soal-soal latihan yang sifatnya penguatan, serta daftar pustaka.

Sebelum digunakan dalam pembelajaran nyata sebagai tahap kedua dalam penelitian ini, materi ajar telah direvisi melalui serangkaian kegiatan, yaitu validasi pakar, simulasi, dan kegiatan ujicoba.

\section{Tahap Peragaan}

Tahap ini merupakan kelanjutan untuk mengembangkan spesifikasi rancangan dan memantapkan kualitas sarana dan media pengembangan produk paling awal, dengan hasil berupa dokumen rinci tentang produk (storyboards, templates dan prototipe media 
bahan belajar). Seluruh perangkat pembelajaran yang telah di buat diujicoba dalam suatu model pembelajaran dengan sintaks model 5 SoEL. Produk pembelajaran yang utama pada tahapan ini adalah proposal kewirausahaan atau business plan yang berupa tugas kelompok (3-4 orang mahasiswa).

Tes hasil belajar produk digunakan untuk mengetahui tingkat penguasaan mahasiswa terhadap materi pelajaran yang diukur dengan menilai kemampuan kognitif dalam pembelajaran. kemampuan kognitif selanjutnya akan ditinjau secara perorangan yang disebut sebagai ketuntasan perorangan, dan dilihat secara keseluruhan mahasiswa yang mengikuti pelajaran dari awal sampai akhir yang disebut sebagai ketuntasan klasikal.

Pelaksanaan penelitian penerapan model 5 SoEL untuk 4 pokok bahasan dengan model 5 SoEL yang telah dikembangkan oleh peneliti, telah dilaksanakan pada mahasiswa angkatan 2008 Pendidikan IPA dan Pendidikan Fisika. Uji coba dilaksanakan Pada bulan September 2010 dengan tiap pokok bahasan diambil 1 sampel Rancangan Pembelajaran, sehingga seluruh ada 4 RPP yang diujicobakan di kelompok kecil ini. Setiap kali tatap muka atau penyampaian satu RP dilakukan pengamatan terhadap kemampuan dosen dalam mengelola KBM yang berorientasi model 5 SoEL dengan instrumen yang telah dikembangkan sebelumnya.

Pelaksanaan penelitian penerapan model 5 SoEL untuk 4 pokok bahasan dengan model 5 SoEL yang telah dikembangkan oleh peneliti, telah dilak- sanakan pada mahasiswa angkatan 2008 Pendidikan IPA dan Pendidikan Fisika. Ujicoba dilaksanakan Pada bulan September 2010 dengan tiap pokok bahasan diambil 1 sampel Rancangan Pembelajaran, sehingga seluruh ada 4 RPP yang diujicobakan dikelompok kecil ini. Setiap kali tatap muka atau penyampaian satu RP dilakukan pengamatan terhadap kemampuan dosen dalam mengelola KBM yang berorientasi model 5 SoEL dengan instrumen yang telah dikembangkan sebelumnya.

\section{Tahap Pengembangan}

Tahap ini adalah tahap lanjutan, yaitu melayani dan membimbing mahasiswa dengan hasil berupa bahan pengajaran secara lengkap, kegiatan intinya adalah upaya meyakinkan bahwa semua rancangan dapat digunakan bagi pengguna dan memenuhi tujuan. Seluruh perangkat pembelajaran yang telah di buat diujicoba dalam suatu model pembelajaran 5 SoEL dengan pendekatan project based learning.

Dalam tahap pegembangan ini peneliti berupaya memadukan 3 macam model dari 5 macam model pembelajaran kewirausahaan menurut Bank, dkk. (1981), yang digunakan untuk menumbuhkan kemampuan penguasaan 5 SoEL, yaitu; model berpikir kreatif, model penelitian kelompok, dan model belajar eksperensial. Sedangkan model kegiatan luar ruangan dan model analisis konnsep tidak secara eksplisit dilakukan meskipun beberapa kegiatan luar ruangan dilakukan juga.

Penggunaan model-model adalah dalam upaya mengembangkan pembe- 
lajaran dengan berbasis teori konstruktivis, sebagaimana dikemukan oleh Suparno (1997:81), yang terpenting dalam teori konstruktivisme adalah bahwa dalam proses pembelajaran mahasiswalah yang harus mendapatkan penekanan. Merekalah yang harus aktif mengembangkan pengetahuan mereka, bukannya dosen atau orang lain. Mereka yang harus bertanggung jawab terhadap hasil belajarnya. Penekanan belajar mahasiswa secara aktif ini perlu dikembangkan. Kreativitas dan keaktifan mahasiswa membantu mereka untuk berdiri sendiri dalam kehidupan kognitif mahasiswa.

Dalam kaitannya dengan pembelajaran berbasis proyek yang merupakan bagian dari model 5 SoEL, maka pendekatan berbasis proyek merupakan konsep belajar yang membantu dosen mengaitkan antara materi yang diajarkan dengan situasi dunia nyata mahasiswa dan mendorong mahasiswa membuat hubungan antara pengetahuan yang dimilikinya dengan penerapannya dalam kehidupan mereka sebagai anggota keluarga dan masyarakat. Dengan konsep itu, hasil pembelajaran diharapkan lebih bermakna bagi mahasiswa. Proses pembelajaran berlansung alamiah dalam bentuk kegiatan mahasiswa bekerja dan mengalami, bukan mentransfer pengetahuan dari dosen ke mahasiswa.

Produk pembelajaran yang berupa business plan pada tahapan ini mulai direalisasikan menjadi rancangan aksi yang ditindaklanjuti dengan penyertaan modal. Agar mahasiswa mendapatkan modal secara mandiri maka yang selanjutnya ditindak lanjuti ada- lah proposal yang kemudian lolos dalam program PKMK yang didanai oleh Direktorat Pendidikan Tinggi Depdiknas. Bentuk usaha yang terealisir adalah; Bakso Krokot (obat asam urat), Minuman Kesehatan Adas Manis (Miss Anis) yang sudah dilengkapi izin Depkes dan Deperindag, Tas Biji Asam, dan Keripik Biji Mahoni (minuman kesehatan).

\section{Tahap Penyajian}

Meskipun tujuan utamanya adalah pengembangan jiwa kewirausahaan yang telah tampak dari jenis usaha yang berkembang melalui penelitian ini (Bakso Krokot Minuman Kesehatan Adas Manis yang sudah dilengkapi ijin Depkes dan Deperindag, Tas Biji Asam, dan Keripik Biji Mahoni), namun sebagai sebuah mata kuliah, maka hasil belajar juga tetap diperhatikan. Ratarata proporsi jawaban benar mahasiswa terhadap Tes Formatif 1 awal adalah 0.26 , dan rata-rata proporsi jawaban benar mahasiswa setelah pembelajaran menggunakan perangkat yang dibuat dengan tiga Tes Formatif berikutnya (Tes formatif 2, 3, dan 4) adalah 0.72. Dengan demikian, terjadi peningkatan rata-rata proporsi jawaban benar mahasiswa sebesar 0.46. Hasil analisis ketuntasan belajar mahasiswa membuktikan, 23 orang mahasiswa atau $88.64 \%$ mahasiswa telah tuntas belajarnya, dari 26 orang mahasiswa yang mengikuti kegiatan belajar mengajar Praktek lapangan dan diskusi. Dengan demikian, secara klasikal mahasiswa telah tuntas belajarnya, karena persentase mahasiswa yang telah tuntas belajarnya berada di atas standar 
ketuntasan yang ditetapkan dalam silabus. Menurut silabus kewirausahaan, kelas dikatakan tuntas, jika 85\% mahasiswa telah tuntas belajarnya, atau 85\% mahasiswa mempunyai $p^{3} 0.65$. Ada peningkatan tingkat kognitifitas antara sebelum dan sesudah perlakuan yang dapat dilihat dengan uji beda dengan uji t. Hal ini menunjukkan bahwa perlakuan yang diberikan cukup signifikan untuk meningkatkan tingkat kognitifitas mahasiswa.

Hasil aktivitas kewirausahaan berupa bidang usaha kreatif yang telah dikembangkan kemudian diberikan pendampingan oleh dosen dan penyertaan modal usaha dari bagian dana penelitian. Tingkat keberhasilan pemasaran jenis usaha yang telah dikembangkan (Bakso Krokot Minuman Kesehatan Adas Manis yang sudah dilengkapi izin Depkes dan Deperindag, Tas Biji Asam, dan Keripik Biji Mahoni), sampai akhir periode penelitian ini masih dalam tahapan sosialisasi dan pemasaran. Dua bulan awal pelaksanaan usaha tidak serta merta mampu menghasilkan keuntungan sesuai dengan harapan semula, hal ini dikarenakan jenis produk usaha masih baru dan masih belum dikenal luas oleh konsumen.

Dari hasil penelitian, Tas Biji Asam yang paling cepat pemasaran produknya karena dapat bekerjasama dengan para pedagang souvenir di tempattempat wisata. Sedangkan kripik biji mahoni paling sulit memasarkannya karena terkendala rasanya yang masih mengandung sedikit rasa pahit. Secara umum kendala utama adalah waktu yang dimiliki mahasiswa karena ter- kendala tugas-tugas kuliah lainnya, terutama karena kebanyakan mahasiswa telah mulai masuk pada penyusunan tugas akhir skripsi.

\section{PENUTUP \\ Kesimpulan}

Hasil penelitian tahun pertama yang dilakukan melalui tahapan penelitian pengembangan (R\&D) telah menunjukkan keberhasilan proses dan produk. Peningkatan proses dan hasil belajar yang cukup signifikan baik dari aspek kognitif, afektif, dan keterampilan berwirausaha. Meskipun secara kuantitatif model yang dikembangkan masih harus diuji melalui tahapan deseminasi namun model hipotetik yang digunakan telah memberikan hasil yang sesuai dengan rancangan awalnya yaitu menghasilkan wirausaha baru berbasis ilmu pengetahuan. Bentuk usaha yang mulai dikembangkan oleh kelompok mahasiswa, diantaranya adalah Bakso Krokot (obat asam urat), Minuman kesehatan Adas Manis (Miss Anis) yang sudah dilengkapi izin dari Depkes dan Derperindag, Tas Biji Asam, Kreipik biji mahoni (kesehatan), dan Insektisida (baru tahap produksi belum pengujian dan pemasaran).

\section{Saran}

Berdasarkan kesimpulan di atas masih ditemukan beberapa kelemahan dalam kegiatan penelitian ini. Oleh karena itu, perlu dilakukan refleksi sebagai umpan balik perencanaan tindakanpenelitan tahun berikutnya. Pengembangan model 5 SoEL memerlukan dukungan secara kelembagaan untuk membangun kemitraan strategis de- 
ngan industri dan dunia kewirausahaan serta bantuan akses modal dengan perbankan. Penerapan model ini juga memerlukan dukungan dana yang cukup besar untuk setiap paket perkuliahan karena itu diperlukan pendanaan pelaksanaan program pembelajaran yang salah satunya melalu kegiatan penelitian ini yang pada tahu pertama dananya sangat banyak yang dipangkas bila dibandingkan dengan proposal pengajuan awal.

\section{UCAPAN TERIMA KASIH}

Penelitian ini tidak akan terlaksana dengan baik tanpa dukungan banyak pihak, baik yang terlibat secara langsung maupun tidak langsung. Untuk itu, terimakasih diucapkan terutama kepada UNY dan DP2M Ditjen Dikti Kemendiknas atas dukungan dana, monitoring, dan evaluasi yang dilaksanakan untuk penjaminan mutu penelitian ini. Masukan yang sangat berharga dari para reviewer di Lembaga Penelitian UNY, teman-teman peneliti dan dosen-dosen pelaksana rooll out ALFHE di UNY.

\section{DAFTAR PUSTAKA}

Adair, J. 1996. Effective Innovation. How to Stay Ahead of the Competition. London: Pan Books.

Byrd, J \& Brown, P.L. 2003. The Innovation Equation. Building Creativity and Risk Taking in Your Organization. San Fransisco: JosseyBass/Pfeiffer. A Wiley Imprint. www.pfeiffer.com.
Borg \& Gall. 1983. "The effects of H\&Son \& Teacher Demonstration Laboratory Methods on Science Achievement in Relation to Reasoning Ability \& Prior Knowledge". Journal of Research in Science Teaching, 26(2), hlm. 12131.

BPS. http:/www.solopos.com/2009/channel/nasional bps-jumlah-penganggur-terdidik-melonjak3258. (diakses tanggal 3 Desember 2009).

Cennamo, K. \& Kalk, D. 2005. Real World Instructional Design. Diambil tanggal 23 September 2007 dari www.Amazon.com.

Dillon, W. R., \& Goldstein, W. 1984. Multivariate Analysis. Columbia: John Wiley \& Sons.

De Jong, J \& Hartog, D D. 2003. Leadership as a determinant of Innovative Behaviour. A Conceptual Framework. http:/wwww.eim.net/pdf-ez/H200303.pdf. 21 April 2006.

De Jong, JPJ \& Kemp, R. 2003. “Determinants of Co-workers's Innovative Behaviour: An Investigation into Knowledge Intensive Service". International Journal of Innovation.

Gay. 1990. The conditions of learning and theory of instruction. 4th edition. New York: Holt, Rinehart, and Winston. 
Hair, J.F., Anderson, R..E., Tatham, R..L., \& Black, W.C. 1998. Multivativariate data analysis (5 ${ }^{\text {th }}$. ed.). New Jersey: Prentice Hall.

Hisrich,R.D., Peters, M.P., dan Shepherd, D.A.2005. Entrepreneurship. Sixth Edition. New York: McGraw-Hill.

Hussey, D.E (eds). 2003. The Innovation Challenge. New York: John Wiley \& Sons.

http://nfomgt.bi.no/euram/material/pluno.doc .
http:Faculty.babson.edu/gordon/ manuscript/ECIS05.doc.

Hyland, P.W \& Beckett, R.C. 2004. Innovation and enhancement of enterprise capabiliti International Journal of Technology Management and Sustainable Development. 3 (1) hlm.35 - 46. (diakses melalui EBSCO Publisher 23 Maret 2005).

Shane, S. 2003. A General Theory of Entrepreneurship.the Individualopportunity Nexus. USA: Edward Elgar. 